\title{
PEMANFAATAN MEDIA DAN PENDEKATAN SAINTIFIK UNTUK MENYATAKAN WAKTU DALAM BAHASA INGGRIS
}

\section{Media Utilization and Scientific Approach to Express Time in English}

\author{
Suwanto \\ SMP Negeri 8 Pontianak \\ Jl. Parit Husin 2, Kota Pontianak, Kalimantan Barat, Indonesia \\ suwantosmpn8@gmail.com
}

\begin{abstract}
ABSTRAK: Penelitian ini bertujuan untuk meningkatkan kemampuan menyatakan dan menanyakan waktu dalam bahasa Inggris, baik secara lisan maupun tertulis dengan menggunakan media dan pendekatan saintifik. Metode penelitian yang digunakan adalah penelitian tindakan kelas (PTK) selama dua siklus. Objek penelitian adalah peserta didik kelas VII- B semester I Tahun Pelajaran 2016/2017 yang berjumlah 35 orang. Instrumen penelitian yang digunakan adalah tes dan nontes. Tes digunakan untuk mengetahui kemampuan menyatakan waktu secara tertulis; sedangkan non-tes yang berupa lembar pengamatan (observasi) digunakan untuk mengetahui berbagai kejadian selama proses kegiatan pembelajaran berlangsung. Hasil observasi dianalisis secara kualitatif dengan mendeskripsikan setiap proses pembelajaran, baik aktivitas guru maupun peserta didik. Hasil penelitian menunjukkan bahwa penerapan pendekatan saintifik dapat meningkatkan kemampuan menyatakan dan menanyakan waktu dalam bahasa Inggris, baik secara lisan maupun tertulis. Pada siklus I, persentase keaktifan peserta didik adalah 53,19\%,dan ini termasuk ke dalam kategori kurang aktif; nilai rata-rata hasil belajar sebesar 75,14; dan ketuntasan sebesar 60\% (21 orang). Pada siklus II, persentase keaktifan peserta didik naik menjadi $76,19 \%$ (kategori aktif); nilai rata-rata hasil belajar sebesar 79,49; dan ketuntasan sebesar 77,14\% (27 orang).
\end{abstract}

Kata Kunci: Media, pendekatan saintifik, waktu

\begin{abstract}
The objective of this research is to at improve students' ability in expressing and asking time in English, in spoken as well as written form, by using media and scientific approach. This research applies classroom action research of two cycles. The object of this research is 35 students of grade VII-B in semester I of 2016/2017 Academic Year. The research instrument is through test and non-test. Test is used to know the students' ability in expressing time in written form; while nontest, which is observation form, is used to know various facts during the learning process. The observation result is then analyzed qualitatively by describing each learning process, from the side of the teacher as well as the students' activities. The
\end{abstract}




\begin{abstract}
research result shows that scientific approach application can improve the students' ability in expressing time, in spoken as well as written form. In the first cycle, the students' activeness percentage is $53,19 \%$, and categorized as less active; learning outcomes average score is 75,14; and learning completeness is 60\% (21 students). In the second cycle, the students' activeness percentage increases to be $76,19 \%$ (active category); learning outcomes average score is $79,49 \%$; and learning completeness is $77,14 \%$ (27 students).
\end{abstract}

Keywords: media, scientific approach, time

\section{PENDAHULUAN}

Nilai rerata ulangan harian mata pelajaran bahasa Inggris adalah 60,88. Kriteria ketuntasan minimal (KKM) khususnya tentang materi pelajaran bahasa Inggris mengenai waktu adalah14,28\% (5 dari 35 peserta didik yang tuntas). KKM yang ditetapkan adalah 75 . Salah satu kelemahan yang cukup mendasar adalah rendahnya kemampuan peserta didik dalam menyatakan dan menanyakan waktu. Berdasarkan observasi langsung saat pembelajaran di kelas VII-B, terdapat 7 dari 35 peserta didik (20\%) yang aktif. Indikator keaktifan yang dimaksudkan adalah peserta didik mampu menyatakan dan menanyakan waktu dalam bahasa Inggris. Terdapat 28 peserta didik yang merasa malu, ragu untuk menyatakan waktu, dan belum berani berbicara karena takut salah. Peserta didik tersebut merupakan peralihan dari SD ke SMP yang baru pertama kali belajar bahasa Inggris. Setelah diklarifikasi ternyata ada di antara peserta didik yang pernah belajar bahasa Inggris di SD dan ada juga yang belum.

Untuk mengatasi masalah tersebut, diterapkanlah pendekatan saintifik dalam pembelajaran bahasa Inggris. Secara ringkas pendekatan saintifik meliputi langkah-langkah: (1) mengamati; (2) menanya; (3) mengumpulkan informasi; (4) mengolah informasi; dan (5) mengomunikasikan. Untuk dapat disebut ilmiah, metode pencarian harus berbasis pada bukti-bukti dari objek yang dapat diobservasi, empiris, dan terukur dengan prinsip-prinsip penalaran yang spesifik (Permendikbud Nomor 81A Tahun 2013a lampiran IV).

Dalam mengaplikasikan pendekatan saintifik, guru berperan sebagai pembimbing dengan memberikan kesempatan kepada peserta didik untuk belajar secara aktif. Dengan bimbingan guru, peserta didik diarahkan pada kegiatan belajar-mengajar dari yang semula berorientasi guru menjadi berorientasi peserta didik (Tung, 2015: 309). Menurut Badan PSDMPK-PMP (2014:15), pembelajaran dengan metode saintifik antara lain didasarkan pada prinsip pembelajaran yang berpusat pada peserta didik, dan membentuk konsep pribadi peserta didik.

Berdasarkan kajian di atas, salah satu cara yang dapat dilakukan guru adalah menerapkan pendekatan saintifik. Langkahlangkah pendekatan saintifik untuk meningkatkan kemampuan menyatakan dan menanyakan waktu adalah: (1) melakukan pengamatan atas suatu fenomenon untuk mengidentifikasi masalah yang ingin diketahui; (2) merumuskan pertanyaan berkaitan dengan masalah yang ingin diketahui dan menalar untuk merumuskan hipotesis atas jawaban sementara; (3) mengumpulkan data atau informasi dengan berbagai teknik; (4) menganalisis data atau informasi untuk menarik simpulan; dan (5) mengomunikasikan simpulan.

Hasil yang diperoleh dari pembelajaran yang menerapkan pendekatan saintifik adalah berupa konsep, hukum, dan prinsip yang dibangun oleh peserta didik dengan bantuan guru. Pada kondisi tertentu, data yang diperlukan untuk menjawab pertanyaan tidak mungkin diperoleh secara langsung oleh peserta didik. Data tersebut perlu dikumpulkan dalam waktu yang lama. Dalam hal ini, guru dapat memberikan data yang digunakan untuk kemudian dianalisis oleh peserta didik. Dari uraian di atas, dapat disimpulkan bahwa penerapan pendekatan saintifik dalam 
pembelajaran untuk meningkatkan kemampuan menyatakan dan menanyakan waktu bagi peserta didik kelas VII-B pada materi waktu dianggap layak (rasional) untuk dibuktikan.

Dalam penelitian ini, yang menjadi masalah adalah rendahnya kemampuan peserta didik untuk menyatakan dan menanyakan waktu dalam bahasa Inggris, baik secara lisan maupun tertulis. Rumusan masalah adalah apakah penerapan pendekatan saintifik dapat meningkatkan kemampuan peserta didik menyatakan dan menanyakan waktu dalam bahasa Inggris, baik secara lisan maupun tertulis. Tujuan penelitian ini adalah meningkatkan kemampuan peserta didik untuk menyatakan dan menanyakan waktu dalam bahasa Inggris, baik secara lisan maupun tertulis dengan menerapkan pendekatan saintifik.

Menurut Permendikbud Nomor $81 \mathrm{~A}$ Lampiran IV Tahun 2013, pendekatan ilmiah dalam pembelajaran meliputi lima aspek, yaitu mengamati, menanya, mengumpulkan informasi/eksperimen, mengasosiasikan/ mengolah informasi; dan mengomunikasikan (Permendikbud, 2013b). Pertama, metode mengamati mengutamakan kebermaknaan proses pembelajaran (meaningful learning). Metode ini memiliki keunggulan tertentu, seperti menyajikan media objek secara nyata, peserta didik senang dan tertantang, dan mudah pelaksanaannya. Metode mengamati sangat bermanfaat bagi pemenuhan rasa ingin tahu peserta didik sehingga proses pembelajaran memiliki kebermaknaan yang tinggi. Dengan metode mengamati (observasi), peserta didik menemukan fakta bahwa ada hubungan antara objek yang dianalisis dengan materi pembelajaran yang dijelaskan guru. Kegiatan belajar yang dapat dilakukan dalam metode mengamati adalah membaca, mendengar, menyimak, dan melihat (tanpa atau dengan alat). Kegiatan ini dapat melatih kesungguhan dan ketelitian dalam mencari informasi.

Kedua adalah menanya. Guru perlu membimbing peserta didik untuk dapat mengajukan pertanyaan. Pertanyaan yang terkait dengan hasil pengamatan objek, mulai dari yang kongkrit sampai dengan yang abstrak berkenaan dengan fakta, konsep, prosedur, atau pun hal lain yang lebih abstrak (Lazim, 2013). Kegiatan "menanya" dalam pembelajaran berarti mengajukan pertanyaan tentang informasi yang tidak dipahami tentang objek yang diamati; atau mengajukan pertanyaan untuk mendapatkan informasi tambahan tentang objek yang diamati (dimulai dari pertanyaan faktual sampai ke pertanyaan yang bersifat hipotetik). Kompetensi yang diharapkan dalam menanya adalah mengembangkan kreativitas, rasa ingin tahu, kemampuan merumuskan pertanyaan untuk membentuk pikiran kritis yang perlu untuk hidup cerdas dan belajar sepanjang hayat.

Ketiga adalah kegiatan mengasosiasi atau mengolah informasi/menalar. Kegiatan mengasosiasi adalah mengolah informasi yang sudah dikumpulkan, baik yang terbatas dari hasil kegiatan mengumpulkan/ eksperimen maupun hasil dari kegiatan mengamati.Pengolahan informasi yang dikumpulkan dari yang bersifat menambah keluasan dan kedalaman sampai dengan pengolahan informasi yang bersifat mencari solusi dari berbagai sumber yang memiliki pendapat berbeda sampai pada yang bertentangan. Kegiatan mengasosiasi dilakukan untuk menemukan keterkaitan satu informasi dengan informasi lainya, menemukan pola dari keterkaitan informasi tersebut. Kompetensi yang diharapkan dari kegiatan menalar ini yaitu mengembangkan sikap jujur, teliti, disiplin, taat aturan, kerja keras, kemampuan menerapkan prosedur dan kemampuan berpikir induktif, serta deduktif dalam menyimpulkan.

Keempat adalah melakukan percobaan atau eksperimen (experimenting). Kegiatan eksperimen ini menjelaskan bahwa untuk memperoleh hasil belajar yang nyata atau otentik, peserta didik harus mencoba atau melakukan percobaan, terutama untuk materi atau substansi yang relevan. Kegiatan pembelajaran yang dapat dilakukan dalam aspek mencoba ini dapat berupa membaca sumber lain selain buku teks, mengamati objek/kejadian/aktivitas, atau melakukan wawancara dengan narasumber. Aplikasi metode eksperimen atau melakukan

percobaan dimaksudkan untuk 
mengembangkan berbagai ranah tujuan belajar yaitu sikap, keterampilan, dan pengetahuan. Kelima adalah kegiatan mengomunikasikan dalam kegiatan pembelajaran. Artinya, peserta didik menyampaikan hasil pengamatan dan kesimpulan berdasarkan hasil analisis secara lisan, tertulis, atau dalam bentuk media lainnya. Adapun kompetensi yang diharapkan dalam kegiatan ini adalah mengembangkan sikap jujur, teliti, toleransi, kemampuan berpikir sistematis, mengungkapkan pendapat dengan singkat dan jelas, serta mengembangkan kemampuan berbahasa yang baik dan benar.

Pada pendekatan saintifik, guru diharapkan memberi kesempatan kepada peserta didik untuk mengomunikasikan apa yang telah dipelajari. Kegiatan ini dapat dilakukan dengan cara menuliskan atau menceritakan apa yang ditemukan dalam kegiatan mencari informasi, mengasosiasikan, dan menemukan pola. Hasil tersebut disampaikan di kelas dan dinilai guru sebagai hasil belajar peserta didik atau kelompok peserta didik (Wijayanti, 2014: 104).

Dalam kegiatan mengamati, diperlukan media seperti gambar dan film. Media sangat membantu peserta didik untuk memahami materi pelajaran. Peserta didik yang mempunyai gaya belajar visual sangat terbantu dengan adanya media tersebut. Kusnandi dan Sutjipto (2013: 8) mengatakan bahwa media pembelajaran adalah alat yang membantu proses belajarmengajar agar tujuan pembelajaran dapat dicapai dan mampu memfasilitasi peserta didik untuk belajar, yaitu dengan membangun pengetahuannya sendiri.

Berdasarkan beberapa pendapat yang telah dikemukakan,dapat disimpulkan bahwa media pembelajaran merupakan alat bantu peserta didik untuk memahami proses pembelajaran secara lebih konkret. Hal tersebut sesuai dengan penelitian Nurhayati tentang pengintegrasian TIK ke dalam pembelajaran berbasis pendekatan saintifik sesuai Kurikulum 2013 yang menunjukkan bahwa salah satu keberhasilan guru adalah merancang pembelajaran dan menuangkannya ke dalam RPP (Nurhayati, 2016: 42). $\begin{array}{ccc}\text { Penggunaan media pembelajaran } & \text { pembelajaran }\end{array}$ menjadi sebuah keharusan bagi guru meskipun terkadang dalam kondisi tertentu, sebagian guru yang minimalis masih memanfaatkan media pembelajaran berupa papan tulis dan alat peraga sederhana tertentu. Akan tetapi, hal ini persentasenya lebih sedikit daripada guru yang memanfaatkan media (Mastur, 2017: 51).

Pendekatan saintifik digadang-gadang agar mampu mengembangkan ranah sikap, pengetahuan, dan keterampilan peserta didik. Pendekatan saintifik dianggap mampu merubah paradigma yang lama yaitu pembelajaran berpusat kepada pendidik (teacher oriented) menjadi pembelajaran berpusat kepada peserta didik (student oriented ) (Ritonga, 2017: 81). Hal ini sesuai dengan pernyataan Keyes (2010: 21), yaitu bahwa the scientific method is an approach to data collection that relies on two assumptions: (1) knowledge about the world is acquired through observation; and (2) the truth of the knowledge is confirmed by verification that is, by others making the same observations. Pendekatan pembelajaran saintifik adalah pola pembelajaran yang mendorong peserta didik agar belajar secara aktif dengan mencurahkan segenap pikirannya secara kritis, analitis, dalam memecahkan masalah pembelajarannya dengan cara mengamati, menanya, mencoba, menalar, menyaji, dan menciptakan.

Pembelajaran berbasis pendekatan saintifik itu lebih efektif hasilnya dibandingkan dengan pembelajaran tradisional. Hasil penelitian membuktikan bahwa pada pembelajaran tradisional, retensi informasi yang diperoleh dari guru sebesar $10 \%$ setelah 15 menit dan perolehan pemahaman kontekstual sebesar $25 \%$. Pada pembelajaran berbasis pendekatan saintifik, retensi informasi yang diperoleh dari guru sebesar $>90 \%$ setelah dua hari dan perolehan pemahaman kontekstual sebesar 50-70\% (Atsnan dan Gazali, 2013: 48).

Hasil penelitian yang dilakukan oleh Marjan, J.,et.al (2014) menyatakan bahwa pembelajaran yang menerapkan pendekatan 
saintifik lebih baik daripada model pembelajaran langsung $(F=70,630 ; p<0,05)$ dalam meningkatkan hasil belajar biologi dan keterampilan proses sains. Dari hasil penelitian tersebut, pendekatan santifik lebih efektif dibandingkan dengan model

pembelajaran langsung sehingga disimpulkan bahwa pembelajaran dengan pendekatan saintifik berperan positif dalam meningkatkan hasil belajar.

Untuk menerapkan pendekatan saintifik, diperlukan kepahaman dan kreativitas guru dalam menyampaikan materi pelajaran. Hal ini dapat dilihat dari segi pemahaman guru terhadap penerapan yang dilakukan. Salah satu kelebihan pendekatan saintifik adalah menciptakan situasi belajar yang menyenangkan (Budiyanto, dkk., 2016: 49). Pembelajaran dengan pendekatan saintifik adalah proses pembelajaran yang dirancang supaya peserta didik secara aktif membangun konsep, hukum, atau prinsip melalui tahapantahapan. Peserta didik mendapatkan, baik pemahaman, mengenal, dan memahami berbagai materi maupun informasi yang berasal dari mana saja, kapan saja, tidak bergantung pada informasi searah dari guru. Oleh karena itu, kondisi pembelajaran diharapkan tercipta, terarahkan untuk mendorong peserta didik dalam mencari tahu dari berbagai sumber melalui observasi, dan bukan hanya diberi tahu. Dalam mencari informasi, bantuan guru diperlukan. Akan tetapi bantuan guru tersebut harus semakin berkurang dalam proses belajar, dengan pembelajaran yang semakin bertambah dewasanya peserta didik atau semakin tingginya kelas siswa (Sumayasa, 2015).

Pembelajaran merupakan proses ilmiah. Itulah sebabnya Kurikulum 2013 mengamanatkan esensi pendekatan saintifik dalam pembelajaran. Pendekatan saintifik diyakini sebagai titian emas perkembangan dan pengembangan sikap, keterampilan, dan pengetahuan peserta didik. Kurikulum 2013 menekankan pada dimensi pedagogik modern dalam pembelajaran, yaitu menggunakan pendekatan saintifik yang terdiri atas kegiatan mengamati (untuk mengidentifikasi hal-hal yang ingin diketahui), merumuskan pertanyaan (merumuskan hipotesis), mencoba/mengumpulkan data (informasi) dengan berbagai teknik, mengasosiasi/menganalisis/mengolah data (informasi) dan menarik kesimpulan serta mengomunikasikan hasil yang terdiri dari kesimpulan untuk memperoleh pengetahuan, keterampilan dan sikap (Yuniarti, 2014).

Kurikulum 2013 menekankan pada dimensi pedagogik modern dalam pembelajaran, yaitu menggunakan pendekatan ilmiah. Pendekatan ilmiah (scientific approach) dalam pembelajaran sebagaimana dimaksud meliputi mengamati, menanya, mencoba, mengolah, menyajikan, menyimpulkan, dan mencipta untuk semua mata pelajaran. Pada mata pelajaran, materi, atau situasi tertentu, sangat mungkin pendekatan ilmiah ini tidak selalu tepat diaplikasikan secara prosedural. Pada kondisi seperti ini, tentu saja proses pembelajaran harus tetap menerapkan nilai-nilai atau sifat-sifat ilmiah dan menghindari nilai-nilai atau sifat-sifat non ilmiah (Mu'arif, \& Surjono, 2016: 198).

\section{METODA}

Metode penelitian yang digunakan adalah Penelitian Tindakan Kelas (PTK) yang bertujuan untuk memperbaiki proses pembelajaran tentang materi waktu dalam pelajaran bahasa Inggris. Subjek penelitian adalah peserta didik kelas VII-B (35 orang) Tahun Pelajaran 2016/2017 di SMPN 8 Pontianak. Penelitian ini dilaksanakan dengan sistem siklus, yaitu Siklus -I dan Siklus-II. Setiap siklus mengacu pada tahapan-tahapan dalam melaksanakan penelitian tindakan kelas. Tahapan tersebut adalah perencanaan, pelaksanaan, observasi, dan refleksi yang dikembangkan oleh Kemmis \& Taggart (1990: 11-12) seperti disajikan pada Gambar 1 berikut ini. 


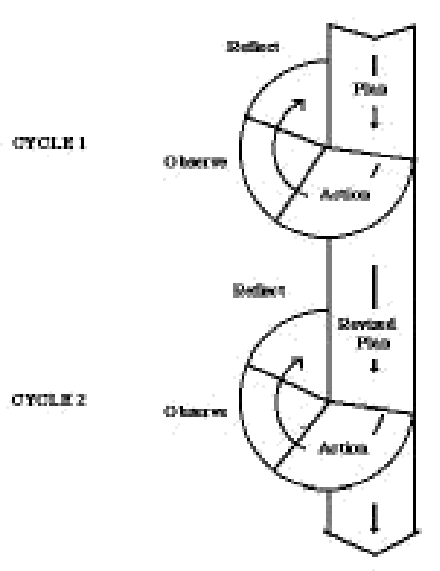

Gambar 1. Siklus Penelitian

Data penelitian ini terdiri dari dua jenis, yaitu data hasil observasi dan data kemampuan menyatakan waktu dalam pelajaran bahasa Inggris dalam bentuk tes tertulis. Data observasi terdiri atas observasi di kelas, baik guru maupun peserta didik. Data observasi peserta didik dianalisis dengan cara mendeskripsikan setiap kegiatan.Untuk mengolah hasil observasi peserta didik, digunakan rumus rata-rata keaktifan=rata-rata peserta didik yang aktif/jumlah peserta didik $\times 100$. Kriteria $10 \%$ sampai $40 \%$ berarti tingkat keaktifan peserta didik masuk dalam kategori "kurang aktif"; $41 \%$ sampai $60 \%$ "cukup aktif"; $60 \%$ sampai $80 \%$ "aktif"; dan $81 \%$ sampai 100\% "sangat aktif".

Analisis data penelitian dilakukan dengan langkah-langkah model Miles dan Huberman (1984: 21-23), yaitu: (1) reduksi data; (2) display/penyajian data; dan (3) mengambil simpulan lalu diverifikasi. Berikut ini disajikan gambar alurnya.

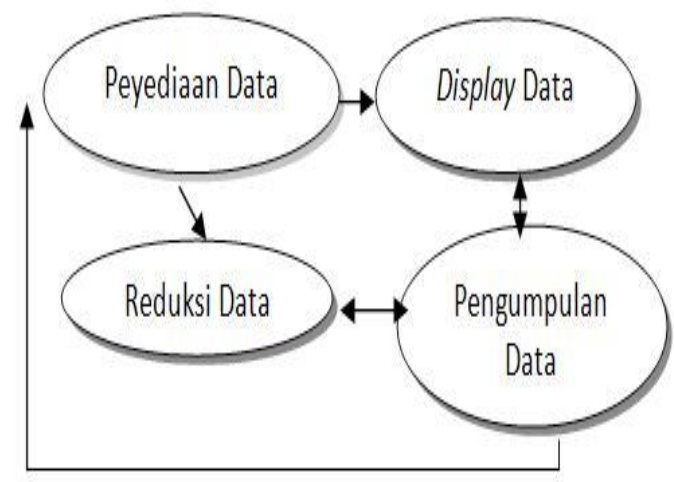

Gambar 2. Analisis Data Kualitatif
Setiap item diberikan skor untuk mengetahui ketuntasan peserta didik secara individu dan ketuntasan secara klasikal dihitung dengan cara berikut ini. Indikator keberhasilan penelitian tindakan kelas ini adalah ketika terdapat minimal 27 dari 35 peserta didik (77\%) yang menunjukkan keaktifannya. Terdapat 5 indikator keaktifan peserta didik yang diukur pada penelitian ini dan dikelompokkan dalam 2 jenis kegiatan, yaitu: (1) visual activities (memperhatikan penjelasan guru); dan (2) oral activities (menyatakan waktu dalam bahasa Inggris).

\section{Siklus-I}

Menyusun perangkat pembelajaran yang meliputi rencana pelaksanaan pembelajaran (RPP), lembar kerja peserta didik, lembar observasi kegiatan guru, dan lembar pengamatan peserta didik. Setelah lembar kerja dibagikan kepada peserta didik, guru melaksanakan tindakan kegiatan pembelajaran sesuai dengan RPP. Materi pelajaran yang disajikan adalah mengenai waktu dalam bahasa Inggris dengan menggunakan media cardboard clock dan pendekatan saintifik. Materi waktu yang disajikan meliputi o'clock, past, a quater, half dan to. Kemudian, guru mengambil/ mengumpulkan data hasil pengamatan aktivitas belajar peserta didik.

Langkah pertama yang dilakukan guru dalam tindakan pembelajaran adalah meminta peserta didik melakukan pengamatan (observasi). Peserta didik mengamati gambar pada buku dan media yang disajikan di depan kelas. Langkah kedua adalah mengondisikan peserta didik untuk mengajukan pertanyaan. Peserta didik memikirkan pertanyaan yang diajukan berdasarkan hasil pengamatannya. Langkah ketiga adalah peserta didik bergerak mencari berbagai sumber ke perpustakaan guna menemukan informasi awal yang dibutuhkan. Dalam hal ini akan memunculkan sebuah hipotesis. Langkah keempat adalah peserta didik menentukan metode dengan melakukan percobaan memutar jam yang disediakan di depan kelas. Langkah terakhir adalah menganalisis data yang telah dikumpulkan dari seluruh percobaan dan menarik simpulan yang dilakukan guru 
bersama peserta didik.

Setelah selesai langkah-langkah tindakan siklus-I, kegiatan berikutnya adalah melakukan observasi.Tujuannya adalah untuk mengetahui kesesuaian rencana tindakan dengan pelaksanaan tindakan pada Siklus-I. Pengamatan dilakukan terhadap aktivitas belajar peserta didik dan kegiatan yang dilaksanakan guru sebagai peneliti. Sebagai tindak lanjut dari kegiatan observasi, peneliti bersama guru (observers) mendiskusikan kekurangan yang ditemukan pada pelaksanaan tindakan siklus-I, menilai hasil pengamatan aktivitas belajar peserta didik, dan menemukan solusi yang harus dilakukan pada siklus-II.

\section{Siklus-II}

Menyusun perangkat pembelajaran yang meliputi RPP, lembar kerja peserta didik, lembar observasi kegiatan guru, lembar pengamatan peserta didik. Kemudian, pada tahap pelaksanaan tindakan, kegiatan yang dilakukan adalah melaksanakan pembelajaran sesuai dengan RPP, dan pengambilan/pengumpulan data hasil pengamatan aktivitas belajar peserta didik. Guru menyampaikan materi pelajaran bahasa Inggris tentang waktu, khususnya materi pelajaran yang dinilai sulit dengan menggunakan media cardboard clockdan pendekatan saintifik. Lembar kerja peserta didik dibagikan kepada peserta didik. Materi pelajaran bahasa Inggris tentang waktu yang dirasakan peserta didik sulit adalah penggunaan half dan to. Observasi dilakukan untuk mengamati kesesuaian rencana tindakan dengan pelaksanaan tindakan pada Siklus-II. Pengamatan dilakukan terhadap aktivitas belajar peserta didik dan kegiatan yang dilaksanakan guru sebagai peneliti.

Peneliti bersama observer mendiskusikan kekurangan yang ditemukan pada pelaksanaan tindakan Siklus-II, menilai hasil pengamatan aktivitas belajar peserta didik, menemukan solusi yang harus dilakukan untuk mengatasi kekurangan yang ditemukan pada proses pelaksanaan pembelajaran sehingga dapat diperbaiki.

\section{HASIL DAN PEMBAHASAN}

\section{Observasi Awal (Baseline)}

Peserta didik mengalami kesulitan dalam mengikuti pembelajaran bahasa Inggris yang membahas tentang materi waktu. Kesulitan tersebut dapat dilihat dalam bentuk kurang atau tidak bergairahnya peserta didik mengikuti pelajaran, komentar yang diucapkan dan gerak-gerik serta ekspresi peserta didik selama berlangsung kegiatan pembelajaran, terlebih lagi pada saat menyatakan dan menanyakan waktu dalam bahasa Inggris. Perolehan hasil belajar peserta didik tentang materi pelajaran mengenai waktu saat ulangan harian sangat rendah. Artinya, proses dan hasil belajar dalam menyatakan dan menanyakan waktu perlu pembenahan.

\section{Hasil Penelitian Siklus-I}

Pada tahap perencanaan, dirancang perangkat dan instrumen pembelajaran. Pada tahap pelaksanaan, materi pelajaran disampaikan kepada peserta didik dengan pendekatan saintifik. Materi pelajaran yang dipelajari pada siklus-I adalah o'clock, past, a quater, half dan to.

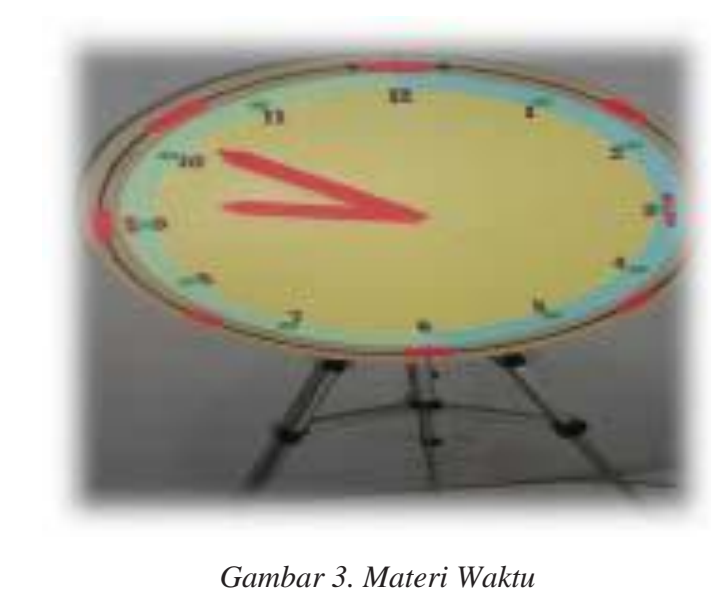

Tahap pertama pendekatan saintifik adalah mengamati. Peserta didik mengamati media yang diberikan guru yaitu cardboard clock. Media tersebut ditampilkan di depan kelas. 


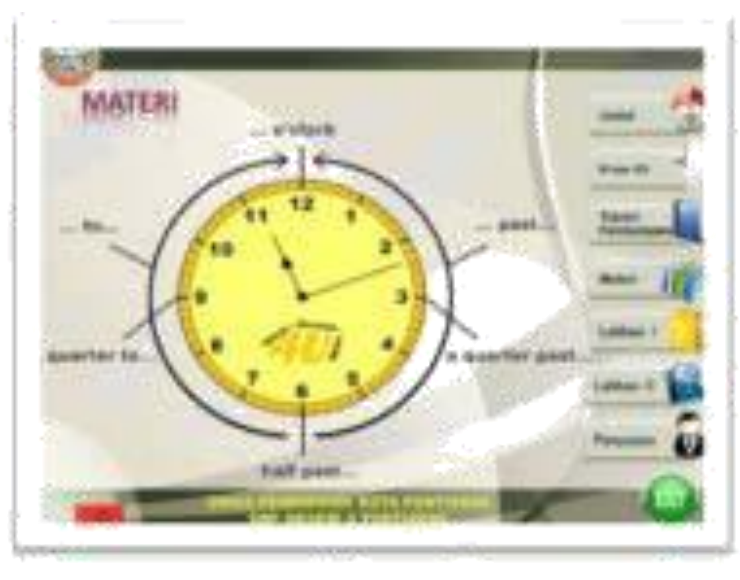

Gambar 4. Media Cardboard Clock

Pada tahap menanya, dengan bimbingan guru, peserta didik mengajukan pertanyaan kepada sesama mereka terkait dengan media yang ditampilkan. Contoh pertanyaannya sebagai berikut. "What time do you get up?", "What time do you have breakfast?","What time is it?". Jawaban peserta didik dapat saja misalnya "At five o'clock", "Atsix o'clock", "A quarter to six" atau "At half past five".

Tahap menalar, guru bersama peserta didik mengolah informasi dari pertanyaan dan jawaban peserta didik tersebut. Pengolahan informasi yang dikumpulkan ada yang bersifat menambah keluasan seperti What time do you go to school? I go to schoolat 6.30 (half past six atau at six thirty).

Tahap mencoba, peserta didik berusaha memeragakan jam sesuai dengan pertanyaan, baik yang diajukan peserta didik maupun pertanyaan yang diberikan guru.

Tahap mengomunikasikan, guru menyampaikan simpulan tentang hasil pekerjaan peserta didik yang sudah memeragakan media cardboard clock.

Hasil observasi Siklus-I adalah guru terlalu cepat menginformasikan materi di depan kelas. Ada lima materi pelajaran yang dibahas, yaitu penggunaan o'clock, past, a quater, half, dan to. Peserta didik tidak atau kurang memahami materi pelajaran khususnya mengenai penggunaan kata past dan to dalam menyatakan waktu.

Kemudian, refleksi dilakukan guru bersama observer dan hasilnya menunjukkan masih adanya kekurangan-kekurangan dalam kegiatan pelaksanaan tindakan sebagaimana yang disajikan pada Tabel 1 berikut ini.

Tabel 1. Hasil Refleksi Siklus-I

\begin{tabular}{ll}
\hline No Kekurangan & $\begin{array}{l}\text { Rencana Tindakan } \\
\text { Siklus-II }\end{array}$ \\
\hline $\begin{array}{l}\text { 1. Peserta didik masih } \\
\text { malu, takut untuk } \\
\text { berinteraksi dengan } \\
\text { yang lain dalam } \\
\text { menyatakan waktu. }\end{array}$ & $\begin{array}{l}\text { Guru diharapkan lebih } \\
\text { memotivasi peserta } \\
\text { didik untuk dapat } \\
\text { bekerja sama dan aktif } \\
\text { berpartisipasi. }\end{array}$ \\
\hline $\begin{array}{l}\text { 2. Guru lupa } \\
\text { menyampaikan tujuan } \\
\text { pembelajaran. }\end{array}$ & $\begin{array}{l}\text { Guru menyampaikan } \\
\text { tujuan pembelajaran di } \\
\text { awal. }\end{array}$ \\
\hline $\begin{array}{l}\text { Kebanyakan peserta } \\
\text { didik masih pasif. }\end{array}$ & $\begin{array}{l}\text { Guru harus bisa } \\
\text { memancing peserta } \\
\text { didik untuk } \\
\text { menyatakan waktu. }\end{array}$ \\
\hline $\begin{array}{l}\text { 4. Peserta didik belum } \\
\text { menguasai materi } \\
\text { pelajaran tentang } \\
\text { waktu. Hal ini bisa } \\
\text { dilihat pada saat } \\
\text { menyatakan waktu } \\
\text { masih melihat buku. }\end{array}$ & $\begin{array}{l}\text { Guru menegaskan saat } \\
\text { menyatakan waktu } \\
\text { tidak perlu melihat atau } \\
\text { membaca buku. }\end{array}$ \\
\hline $\begin{array}{l}\text { W. Waktu memeragakan di depan kelas } \\
\text { diperlukan waktu } \\
\text { yang relatif lama. }\end{array}$ & $\begin{array}{l}\text { Penjelasan materi } \\
\text { pelajaran tentang } \\
\text { waktu perlu } \\
\text { diulangsehingga } \\
\text { peserta didik paham } \\
\text { tanpa melihat buku. }\end{array}$ \\
\hline
\end{tabular}

Berdasarkan hasil refleksi Siklus-I, rencana tindakan pada Siklus-II dilaksanakan.

\section{Hasil Pengamatan Peserta Didik Siklus-I}

Aktivitas belajar peserta didik pada Siklus-I diukur dengan menggunakan lembar pengamatan. Hasil pengamatan aktivitas belajar peserta didik dapat dilihat pada Tabel 1. Penilaian aktivitas belajar peserta didik pada Siklus-I untuk indikator: (1) mengamati mencapai 83,81\% termasuk kategori aktif;

(2) indikator menanya mencapai 52,38\% termasuk kategori cukup aktif; (3) indikator menalar mencapai $44,76 \%$ termasuk kategori kurang aktif; dan (4) indikator mengomunikasikan $\quad 37,14 \% \quad$ mencapai $37,14 \%$, termasuk kategori kurang aktif. Ratarata keseluruhan indikator aktivitas belajar peserta didik hanya mencapai 52,19\%, termasuk kategori kurang aktif. Hasil tersebut 
belum memenuhi indikator keberhasilan yang telah ditentukan sebesar $75 \%$ sehingga perlu dilaksanakan Siklus-II.

Tabel 2. Aktivitas Belajar Siklus-I

\begin{tabular}{|c|c|c|c|c|c|c|c|c|c|c|c|c|c|c|c|}
\hline \multirow[t]{2}{*}{ Keterangan } & \multicolumn{3}{|c|}{ Mengamati } & \multicolumn{3}{|c|}{ Menanya } & \multicolumn{3}{|c|}{ Menalar } & \multicolumn{3}{|c|}{ Mencoba } & \multicolumn{3}{|c|}{ Mengomunikasikan } \\
\hline & $\mathrm{KA}$ & $\mathrm{CA}$ & $\mathrm{A}$ & $\mathrm{KA}$ & $\mathrm{CA}$ & A & $\mathrm{K}$ & $\mathrm{CA}$ & A & $\mathrm{K}$ & $\mathrm{CA}$ & $A$ & $\mathrm{~K}$ & $\mathrm{CA}$ & $\mathrm{A}$ \\
\hline Jumlah Siswa & 5 & 7 & 23 & 19 & 12 & 4 & 27 & 4 & 3 & 28 & 4 & 3 & 30 & 3 & 2 \\
\hline JumlahSkor & 5 & 14 & 69 & 19 & 24 & 12 & 27 & 8 & 12 & 28 & 8 & 9 & 30 & 3 & 6 \\
\hline Rata Rata & \multicolumn{3}{|c|}{29,33} & \multicolumn{3}{|c|}{18,33} & \multicolumn{3}{|c|}{15,67} & \multicolumn{3}{|c|}{15,00} & \multicolumn{3}{|c|}{13,00} \\
\hline Presentase & \multicolumn{3}{|c|}{$83,81 \%$} & \multicolumn{3}{|c|}{$52,38 \%$} & \multicolumn{3}{|c|}{$44,76 \%$} & \multicolumn{3}{|c|}{$42,86 \%$} & \multicolumn{3}{|c|}{$37,14 \%$} \\
\hline
\end{tabular}

Ket:. KA: Kurang Aktif $C A$ : Cukup Aktif $A$ : AKtif

\section{Hasil Pengamatan Guru Siklus-I}

Berdasarkan hasil konsultasi dengan teman sejawat, ada masukan-masukan yang digunakan untuk perbaikan dalam melakukan tindakan pada Siklus-II. Instrumen Penilaian Kinerja Guru (IPKG) 1 merupakan instrumen yang digunakan untuk menilai kesesuaian perangkat pembelajaran meliputi tujuan, materi, media, kegiatan dan hasil. Instrumen Penilaian Kinerja Guru (IPKG) 2 merupakan instrumen yang digunakan untuk menilai pelaksanaan pembelajaran dari kegiatan pendahuluan, inti, dan penutup. Hasil IPKG 1 dan 2 dapat dilihat pada Gambar 5 berikut ini.

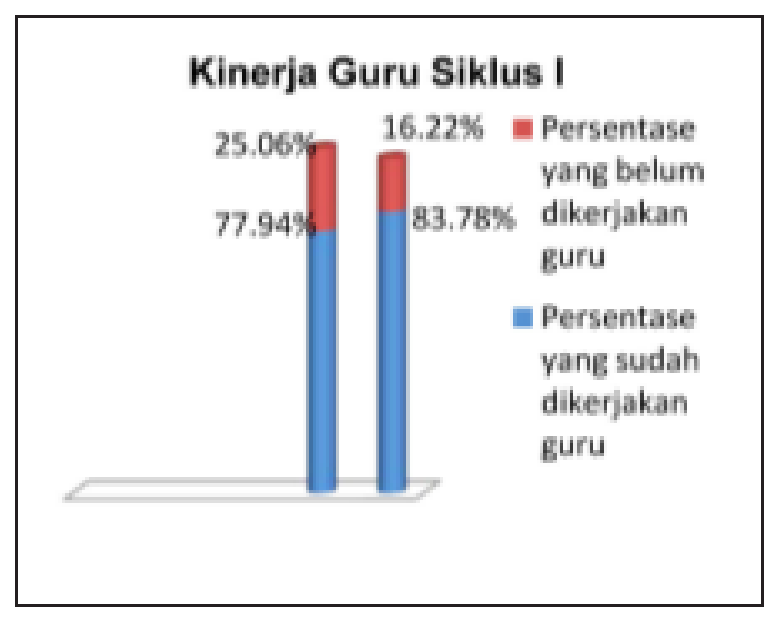

Gambar 5. Kinerja Guru Siklus-I

Berdasarkan Gambar 6,ada 25,06\% dan $16,22 \%$ yang guru belum kerjakan pada saat pelaksanaan pembelajaran. Hal yang belum dikerjakan tersebut akan diperbaiki pada Siklus-II.

\section{Hasil Penelitian Siklus-II}

Siklus-II merupakan perbaikan dari SiklusI dan diharapkan pelaksanaan tindakan berjalan sesuai rencana yang telah disusun serta alokasi waktu benar- benar sesuai dengan yang telah dirancang di dalam RPP. Hasil observasi Siklus-II adalah bahwa pelaksanaan pembelajaran dengan pendekatan saintifik berjalan sangat baik. Interaksi antarpeserta didik sangat baik dibandingkan dengan Siklus-I. Peserta didik terlihat lebih berani menyatakan dan menanyakan waktu dalam bahasa Inggris, baik secara lisan maupun tertulis.

Berdasarkan hasil observasi, dilakukan refleksi dengan observer pada tindakan Siklus-II, proses pembelajaran dan aktivitas belajar yang telah mengalami perubahan. Peserta didik lebih siap mengikuti materi pembelajaran bahasa Inggris tentang waktu. Peserta didik lebih aktif belajar, berani, dan tidak malu, baik menyatakan maupun menanyakan waktu dalam bahasa Inggris.

Hasil Pengamatan Peserta Didik SiklusII Aktivitas belajar peserta didik pada Siklus-II diukur dengan menggunakan lembar pengamatan seperti pada Siklus-II. Hasil pengamatan Siklus-II dapat dilihat pada Tabel 3 berikut ini. 
Tabel 3. Aktivitas Belajar Siklus-II

\begin{tabular}{|c|c|c|c|c|c|c|c|c|c|c|c|c|c|c|c|}
\hline \multirow[t]{2}{*}{ Keterangan } & \multicolumn{3}{|c|}{ Mengamati } & \multicolumn{3}{|c|}{ Menanya } & \multicolumn{3}{|c|}{ Menalar } & \multicolumn{3}{|c|}{ Mencoba } & \multicolumn{3}{|c|}{ Mengomunikasikan } \\
\hline & $\mathrm{KA}$ & $\mathrm{CA}$ & $\mathrm{A}$ & $\mathrm{KA}$ & $\mathrm{CA}$ & $\mathrm{A}$ & $\mathrm{K}$ & $\mathrm{CA}$ & A & $\mathrm{K}$ & $\mathrm{CA}$ & $\mathrm{A}$ & $\mathrm{K}$ & $\mathrm{CA}$ & $\mathrm{A}$ \\
\hline Jumlah Siswa & 1 & 2 & 30 & 8 & 10 & 17 & 9 & 8 & 18 & 10 & 8 & 17 & 14 & 7 & 14 \\
\hline JumlahSkor & 1 & 4 & 90 & 8 & 20 & 51 & 9 & 16 & 54 & 10 & 16 & 51 & 14 & 14 & 42 \\
\hline Rata Rata & \multicolumn{3}{|c|}{31,67} & \multicolumn{3}{|c|}{26,33} & \multicolumn{3}{|c|}{26,33} & \multicolumn{3}{|c|}{25,67} & \multicolumn{3}{|c|}{23,33} \\
\hline Presentase & \multicolumn{3}{|c|}{$90,48 \%$} & \multicolumn{3}{|c|}{$75,24 \%$} & \multicolumn{3}{|c|}{$75,24 \%$} & \multicolumn{3}{|c|}{$73,33 \%$} & \multicolumn{3}{|c|}{$66,67 \%$} \\
\hline
\end{tabular}

Ket:: KA: Kurang Aktif CA : Cukup Aktif $A$ : AKtif

Rata-rata keseluruhan indikator aktivitas belajar peserta didik mencapai 76,19\% yang berarti termasuk kategori aktif. Hasil tersebut telah melebihi indikator keberhasilan yang ditentukan sebesar $75 \%$.

\section{Hasil Pengamatan Guru Siklus-II}

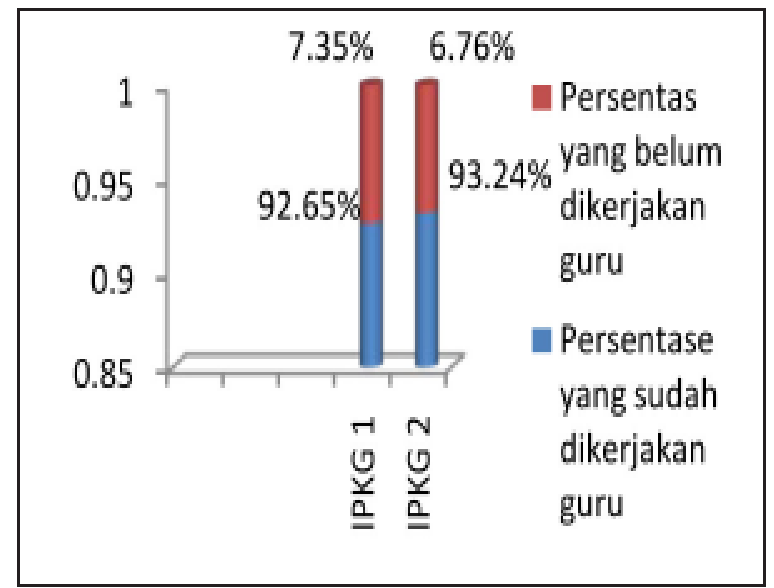

Gambar 6. Kinerja Guru Siklus-II

\section{Hasil Belajar Peserta Didik}

Peningkatan hasil belajar peserta didik dapat diketahui dari hasil Siklus-I dan II yang diberikan setiap awal dan akhir pembelajaran dengan implementasi pembelajaran saintifik sebagaimana yang disajikan pada Tabel 4. berikut ini.
Dari hasil perolehan pratindakan, SiklusI, dan Siklus-II, peneliti banyak menemukan perubahan pada perolehan hasil belajar peserta didik meskipun ada beberapa peserta didik yang memiliki nilai tetap, ada yang mengalami peningkatan, dan bahkan ada yang mengalami penurunan. Hal ini disebabkan adanya kekeliruan dalam jalannya pembelajaran atau jawaban peserta didik yang masih kurang tepat. Perbandingan pratindakan, Siklus-I, dan Siklus- II dapat dilihat pada diagram batang gambar 7 berikut ini.

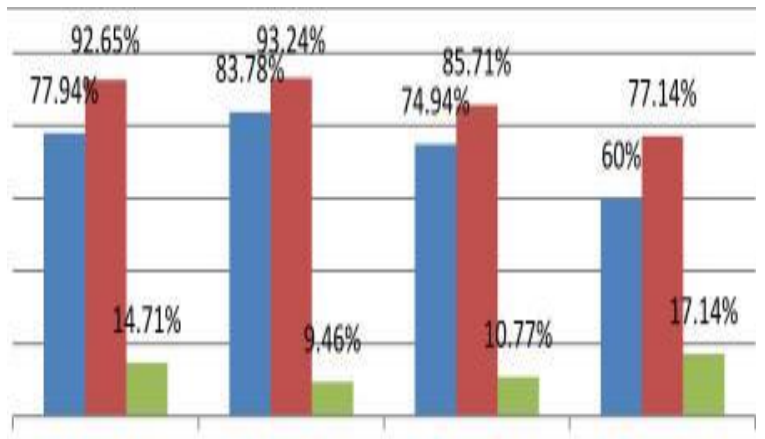

IPKG1 IPKG2 Keaktifan Siswa Hasil Tes -ISiklus |

Gambar 7. Diagram Siklus-I \&Siklus-II

Tabel 4. Hasil Ketuntasan Belajar Peserta Didik Per Siklus

\begin{tabular}{llrllll}
\hline No & Siklus & Peserta & \multicolumn{3}{c}{ Hasil Belajar Peserta Didik } & Rata-rata \\
\cline { 4 - 6 } & & Didik & \multicolumn{2}{c}{ Tidak Tuntas $\leq 75$} & \multicolumn{1}{c}{ Tuntas $\geq 75$} \\
\hline 1. & Pratindakan & 35 & $88,58 \%(31$ orang) & $11,42 \%(4$ orang) & 60 \\
\hline 2. & Siklus-I & 35 & $40 \%(14$ orang $)$ & $60 \%(21$ orang $)$ & 75,14 \\
\hline 3. & Siklus-II & 35 & $22,86 \%(8$ orang) & $77,14 \%(27$ orang $)$ & 79,43 \\
\hline
\end{tabular}


Dari Gambar 7 di atas, dapat dijelaskan bahwa: (1) persentase IPKG 1 yang telah dilakukan guru sebagai peneliti, ada peningkatan siklus I dan II sebesar 4,41\%;

(2) persentase IPKG 2 aspek yang telah dilakukan guru terjadi peningkatan sebesar 3,33\%; (3) sikap keaktifan belajar, ada peningkatan sebesar $11,61 \%$; dan (4) hasil tes siklus yang dilaksanakan diakhir setiap siklus terjadi peningkatan sebesar $22,86 \%$.

Media cardboard clock didesain berbasis pendekatan saintifik. Hosnan (2014:34) mengatakan bahwa pendekatan saintifik merupakan proses pembelajaran yang dirancang sedemikian rupa supaya peserta didik secara aktif dapat membangun konsep, hukum atau prinsip melalui tahapan-tahapan dalam metode ilmiah. Penggunaan pendekatan saintifik atau pendekatan ilmiah bertujuan untuk membiasakan peserta didik secara aktif mengembangkan keterampilan mengamati, mengklasifikasi, mengukur,

meramalkan, menjelaskan, dan menyimpulkan. Peserta didik dibantu untuk belajar membangun pemahamannya sendiri melalui pengalaman belajar yang didapatkan selama proses pembelajaran berlangsung.

Media pembelajaran (termasuk media proyeksi) berperan penting dalam menunjang keberhasilan proses belajar-mengajar. Salah satu fungsi media pembelajaran adalah sebagai alat bantu yang digunakan guru untuk: (1) membantu memperjelas materi yang disampaikan dan mengurangi proses pembelajaran secara verbalisme (Isyani, 2016: 159) dan (2) meningkatkan motivasi belajar, memperjelas dan mempermudah konsep yang abstrak, dan mempertinggi daya serap atau retensi belajar. Alat bantu yang mula-mula digunakan adalah alat bantu visual yaitu berupa sarana yang dapat memberikan pengalaman visual kepada peserta didik (Alawayih, T. 2017: 50). Sebanyak 14 peserta didik $(87,5 \%)$ mampu mencapai nilai KKM 75, dari target keberhasilan sebanyak $80 \%$. Dengan demikian, dapat dikatakan bahwa penggunaan media proyeksi dalam kegiatan pembelajaran berhasil meningkatkan kompetensi peserta didik.

Berdasarkan gambar yang penunjuk waktu yang digunakan guru, sebagian besar peserta didik bingung untuk menuliskan penggunaan kata past dan to di atas kertas lembar jawaban peserta didik. Berarti bahwa pemahaman peserta didik tentang past dan to belum berhasil. Dalam siklus berikutnya, tahap pemahaman past dan to harus diterjemahkan secara lebih baik sehingga mendorong peserta didik dapat menanyakandan menyatakan waktu terutama menggunakan kata past dan to dengan benar.

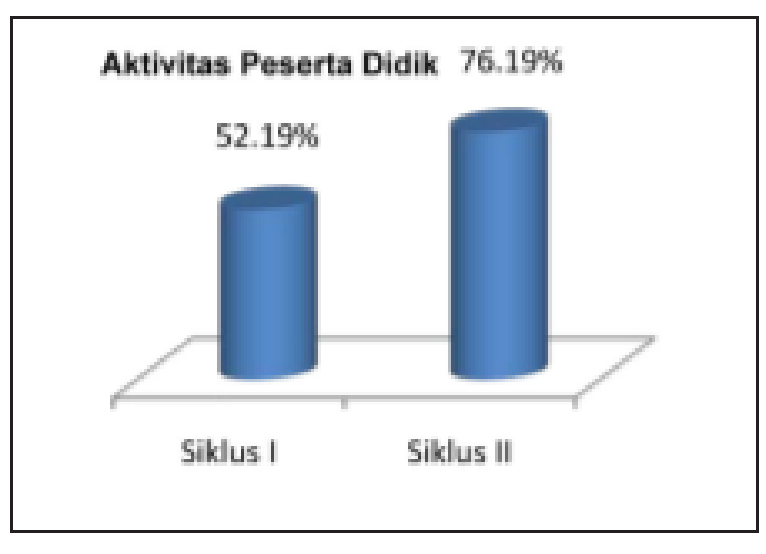

Gambar 8. Perbandingan Aktivitas

Untuk menciptakan proses pembelajaran yang menarik dan menyenangkan dibutuhkan adanya media pembelajaran yang menunjang proses pembelajaran. Penggunaan media

pembelajaran berfungsi untuk mengkonkretkan pemahaman peserta didik kedalam suatu wujud yang lebih nyata sehingga diharapkan peserta didik lebih mudah memahami proses pembelajaran.

Proses pembelajaran pada Kurikulum 2013 untuk satuan pendidikan SMP dan SMA atau yang sederajat dilaksanakan menggunakan langkah-langkah pendekatan ilmiah. Seluruh mata pelajaran diintegrasikan dengan pendekatan ilmiah termasuk proses pembelajaran mata pelajaran bahasa Inggris. Proses pembelajaran menyentuh tiga ranah, yaitu sikap, pengetahuan, dan keterampilan. Harapannya hasil akhirnya adalah peningkatan dan keseimbangan antara kemampuan untuk menjadi manusia yang baik (soft skills) dan manusia yang memiliki kecakapan dan pengetahuan untuk hidup secara layak (hard skills) dari peserta didik yang meliputi aspek kompetensi sikap, keterampilan, dan pengetahuan. 
Pendekatan saintifik yang dimaksud merupakan suatu pendekatan dalam proses pembelajaran yang melibatkan aktivitas ilmiah di dalamnya peserta didik berperan sebagai seorang peneliti yang sedang mencari jawaban dari permasalahan yang dihadapi dalam kegiatan pembelajaran. Pendekatan saintifik pada materi waktu menjadi basis dalam pengembangan materi dan konten yang disajikan. Langkah-langkah pendekatan saintifik diadaptasi untuk menyusun langkah kegiatan pembelajaran bahasa Inggris menggunakan media.

\section{SIMPULAN DAN}

\section{SARAN Simpulan}

Berdasarkan hasil analisis data, dapat disimpulkan bahwa pemanfaatan media dan penerapan pendekatan saintifik dapat meningkatkan kemampuan peserta didik menyatakan dan menanyakan waktu dalam bahasa Inggris, baik secara lisan maupun tertulis. Pada Siklus-I, persentasi keaktifan peserta didik adalah 53,19\% yang berarti masih termasuk kategori kurang aktif, nilai rata-rata hasil belajar sebesar 75,14 dan ketuntasan sebesar 60\% (21 dari 35 orang). Pada Siklus-II, persentasi keaktifan peserta didik naik menjadi $76,19 \%$ yang berarti termasuk kategori aktif, nilai rata-rata hasil belajar sebesar 79,49 dan ketuntasan sebesar $77,14 \%$ (27 orang).

\section{Saran}

Guru melaksanakan pembelajaran dengan pendekatan saintifik untuk mendukung terpenuhinya tuntutan perubahan, baik pada guru maupun peserta didik. Selain itu, perlu dikembangkan media pembelajaran yang bisa dimanfaatkan guru dalam membelajarkan peserta didiknya. Media pembelajaran sederhana dapat dikembangkan guru sesuai dengan kondisi lingkungan yang ada. Manakala diperlukan dan sesuai dengan kondisi yang ada, guru dapat juga memanfaatkan media proyeksi dan atau yang sejenisnya dalam membelajarkan peserta didiknya.

\section{PUSTAKA ACUAN}

\section{Buku}

Hosnan. (2014). Pendekatan Saintifik dan Kontekstual dalam Pembelajaran Abad 21. Bogor: Ghalia Indonesia.

Kemmis, S.dan McTaggart, R. (1990). The Action Research Planner. Victoria: Deaken University Press.

Kusnandi, C. dan Sutjipto, B. (2013). Media Pembelajaran Manual dan Digital. Bogor: Ghalia Indonesia.

Miles, M.B. dan Huberman, A.M. (1984). Qualitative Data Analysis. California: Sage Publications.

Tung,K.Y.(2015). Pembelajaran dan Perkembangan Belajar. Jakarta: Indeks.

\section{Jurnal/Prosiding/Disertasi/Tesis/Skripsi}

Alawayih, T. (2017). Penerimaan Informasi melalui Digital Talking Book oleh Siswa Tuna Netra. Jurnal Teknodik Vol. 21 Nomor 1, Juni 2017. hal 44-58.

Atsnan, M. F. \& Gazali, R. Y. (2013). Penerapan Pendekatan Scientifik dalam Pembelajaran Matematika SMP Kelas VII Materi Bilangan (Pecahan). Prosiding Seminar Nasional Matematika, ISBN: 978-979-16353-9-4.

Budiyanto, M.A.K, Waluyo, L., dan Mokhtar, A. (2016). Implementasi Pendekatan Saintifik dalam Pembelajaran di Pendidikan Dasar di Malang. Proceeding Biology Education Conference, Vol. 13 (1) Tahun 2016 hal. 46-51.

Isyani. (2016). Media Gambar yang Diproyeksikan untuk Meningkatkan Keterampilan Menulis Puisi pada Siswa Kelas 3 SD Banyuripan.

Jurnal Teknodik Vol. 20-Nomor 2, Desember 2016, hal. 155-170.

Keyes, G. (2010). Teaching the scientific method in the social sciences. The Journal of Effective Teaching, 10(2), pp. 18-28. Retrieved from http://www.uncw.edu/jet/ articles/Vol10_2/Volume1002.pdf

Marjan, J., Arnyana, I.B.P, Setiawan, I.G.A.N. (2014). Pengaruh Pembelajaran Pendekatan Saintifik terhadap Hasil Belajar Biologi dan Keterampilan Proses Sains Siswa MA Mu'allimat NW Pancor Selong Lombok Timur, NTT. E-Jurnal Program Pascasarjana 
Universitas Pendidikan Ganesha Volume 4

Tahun 2014, hal. 1-12.

Mastur. (2017). Implementasi Kurikulum 2013 dalam Pelaksanaan Pembelajaran di SMP.

Jurnal Inovasi Teknologi Pendidikan Volume 4, No 1, April 2017. hal 50-64.

Mu'arif, H.A.\& Surjono, H.D. (2016). Pengembangan E-Learning Berbasis Pendekatan IImiah pada Mata Pelajaran IPA di SMP Negeri 5 Yogyakarta. Jurnal Inovasi

Teknologi Pendidikan Volume 3, Nomor 2, Oktober 2016, hal. 195-207.

Nurhayati, A.S. (2016). Mengintegrasikan TIK dalam Pembelajaran Berbasis Pendekatan

Saintifik sesuai Kurikulum 2013. Jurnal

Teknodik, Vol. 201 Nomor 1, Juni 2016, hal. 29-46.

Ritonga, A. A. (2017). Pendekatan Saintifik Pembelajaran Agama pada Sekolah Dasar Terpadu. Jurnal Miqot Vol. XLI No. 1 Juni 2017, hal. 78-97.

Sumayasa, I.Y. (2015). Pengaruh implementasi Pendekatan Scientific Approach Terhadap Motivasi Belajar dan Hasil Belajar Bahasa Indonesia pada Siswa Kelas VI di Sekolah Dasar Segugur VI Kecamatan Abang,

Karangasem. E-Jurnal Program Pascasarjana Universitas Pendidikan Ganesha Program Studi Pendidikan Dasar, 5 (1): 1-13.

Wijayanti, A. (2014). Pengembangan Autentik Assesment Berbasis Proyek dengan Pendekatan Saintifik untuk Meningkatkan
Keterampilan Berfikir Imiah Mahasiswa. Jurnal Pendidikan IPA Indonesia Vol. 3 No. 2 Tahun 2014, hal.102-108.

Yuniarti. (2014). Pengembangan Perangkat Pembelajaran Berbasis Masalah (Problem Based Learning) dengan Pendekatan IImiah (Scientific Approach) Pada Materi Segitiga Kelas VII SMP Se-Kabupaten Karanganyar Tahun Pelajaran 2013/2014. Jurnal

Elektronik Pembelajaran Matematika Vol. 2 (9): 911-921.

\section{Lain-lain}

Badan PSDMPK-PMP. (2014). Materi Pelatihan Guru Implementasi Kurikulum 2013 Tahun 2014. Jakarta: Kemendikbud.

Permendikbud. (2013) a. Lampiran IV Peraturan Menteri Pendidikan dan Kebudayaan Republik Indonesia Nomor 81a Tahun 2013 Tentang Implementasi Kurikulum, Pedoman Umum Pembelajaran. Jakarta: Kementerian Pendidikan dan Kebudayaan.

Permendikbud. (2013).b Materi Pelatihan Guru. Implementasi Kurikulum 2013 SMP/MTs IImu Pengetahuan Alam. Jakarta: Kementerian Pendidikan dan Kebudayaan.

Lazim, M. (2013). Penerapan Pendekatan Saintifik dalam Pembelajaran Kurikulum 2013. https:// www.google.comwebhp?sourceid=chromeinstant\&ion $=1$ \&espv $=2 \&$ ie $=$ UTF- $8 \# q=$ langkah langkah+pendekatan+saintifik\& revid= 1727758164 (Diakses 14 Juli 2018). 